\title{
Consumer choice
}

\author{
H. G. Clarke
}

The author argues that traditional market research techniques such as consumer 'intention to buy' surveys fail to predict consumer behaviour because the underlying assumptions that man is rational, aware of his wants and preferences, and consistent in his buying behaviour, are invalid. He suggests that many economic terms such as 'utility' and 'rationalization' have little practical value; that economic theory ignores a vital element in consumer behaviour - mass communication and the art of persuasion. In searching for a more meaningful approach, the author suggests that many new markets come about as a result of social and environmental change and that, in such cases, the historic process of extrapolating past trends into the future serves little purpose. Rather, the marketer should concentrate on developing a keen understanding of social movements which affect the firm such as consumerism. Yet even knowledge of such movements may serve little purpose because the individual will 'strike out' against subjugation to any movement and will attempt to establish his own identity whatever the cost.

S. Afr. J. Bus. Mgmt 1979, 10. 41-45

Die skrywer redeneer dat tradisionele marknavorsingstegnieke soos opnames oor verbruikers se 'voorneme om te koop', nie daarin slaag om verbruikersgedrag te voorspel nie weens die ongeldigheid van die onderliggende aannames: dat die mens rasioneel is; dat hy bewus is van sy begeertes ('wants') en voorkeure; dat hy konsekwent is in sy koopgedrag. Hy stel dit dat baie ekonomiese begrippe soos 'utiliteit' en 'rasionalisering' min praktiese waarde het; dat ekonomiese teorie 'n hoogs belangrike element in verbruikersgedrag verontagsaam - massakommunikasie en die oorredingskuns. In die soektog na 'n meer betekenisvolle benadering, word voorgestel dat baie nuwe markte tot stand kom weens omgewings- en sosiale veranderinge, en dat in sulke gevalle, die historiese proses van ekstrapolering van neigings uit die verlede tot in die toekoms, weinig nut het. Die bemarker moet liewer daarop konsentreer om 'n deeglike begrip te ontwikkel van sosiale bewegings wat die firma raak - soos verbruikersdruk. Tog mag selfs kennis van sulke bewegings min waarde hê omdat die individu hom mag 'opruk' teen onderwerping aan enige beweging, en sal poog om ongeag die koste, sy eie identiteit te bevestig.

S. Afr. Tydskr. Bedrytsl. 1979, 10: 41-45

H. G. Clarke

68 Dean Street. Newlands 7700

Lewis Stores, Cape Town
A basic feature of capitalism is freedom of choice by consumers. Under normal trading conditions consumers are free to spend or save money as they like, free to select goods according to their tastes and preferences - limited only by the size of their income and the availability of merchandise they want. The way in which consumers choose to spend their money is of vital importance to the marketer, as this affects not only present markets but also indicates where future growth lies.

\section{Difficulties of Assessing Future Markets}

Assessing future markets through an analysis of buying trends is a difficult task because: 'The plain truth is that we can never - except by an act of great faith - say that an existing trend will be maintained even for a short time ahead. Those financiers who have the best advice and who most pride themselves on their ability to predict what is going to happen are the very ones who jump out of the highest windows of skyscrapers when the storm breaks. Economic forecasting, like weather forecasting in England, is only valid for the next six hours or so. Beyond that it is sheer guesswork.' 1 Despite this criticism most marketers maintain that future actions are predictable to a certain degree. They base their arguments on the assumption that human behaviour is consistent, that man will behave in the future much as he has behaved in the past. 'Basic, vital needs have always been, and still are, essentially the same. So are the force and urgency of the drives to satisfy these needs. Only the external shells of needs and drives have changed. ${ }^{2}$ For most marketers the sales forecast, updated on a continuous basis, remains an essential business function.

Nevertheless, the question arises: to what degree can we make valid statistical inferences about the future? Activities such as long range planning, sales forecasting, and optimizing of inventory levels depend upon the consumer acting in a reliable and consistent manner. Yet man seems notoriously unreliable both as an individual and in society. Although it might seem reasonable to extrapolate well-defined trends into the not too distant future in order to make predictions, all too often unforeseen circumstances outside the marketers' control (such as war, nationalization, embargoes) make forecasts completely inaccurate.

The contrary of a predictable world is an unpredictable 
one. Such a world would make nonsense of the marketer's logical functions of planning, organizing, co-ordinating, controlling and implementing his Marketing Plan. Nevertheless, it can be argued that a world, in which actions and decisions are made 'by chance' or 'as a result of a rapidly changing series of inputs', is possible.

\section{Research Results}

The results of a number of surveys give strength to this argument. In a survey of consumers buying durable goods ${ }^{3}$ $52 \%$ of the families interviewed said that they planned making a major purchase during the next six months, while $48 \%$ stated that they did not expect to make a major purchase during that period. Of those who said they would make a major purchase, $53,9 \%$ actually did so. Of those who said they would not make a major purchase, almost 59 per cent did'.

So be it; the chances were about 50-50 that consumers would not perform as they thought they would. By a remarkable coincidence spinning a coin as a basis for decision-making brings about almost exactly the same results. (Tables 1 and 2 ).

Table 1 Probability of coin spinning

\begin{tabular}{llc}
\hline First throw & Heads $-50 \%-$ Heads & Tails $-50 \%-$ Tails \\
\hline Second throw & Heads 50\% Tails 50\% & Heads 50\% Tails 50\% \\
\hline
\end{tabular}

Table 2 Probability of making purchase (example given)

\begin{tabular}{lll}
\hline Intention & Purchase $-52 \%$ - Purchase & No purchase $-48 \%$ - No purchase \\
\hline Action & Purchase $54 \%$ No purchase $46 \%$ & Purchase $59 \%$ No purchase $41 \%$ \\
\hline
\end{tabular}

It would seem, therefore, that consumers frequently act in such a way as to render their behaviour unpredictable.

It might be felt that this is an isolated instance, an example which 'fits perfectly'. Not so; numerous research reports substantiate the difficulty of predicting consumer behaviour patterns. And why? Because 'most people do not plan purchases, even of expensive items, very far ahead, and they cannot honestly tell at the beginning of the year what they will buy before the year is over. Plans to buy durable goods are constantly changing. Well-considered plans to buy are abandoned and new needs and desires are continually being developed. ${ }^{4}$

This variance between what a consumer intends to buy and what he does buy applies not only to those commodities requiring considerable capital outlay (consumer durables), but equally to consumer non-durables. So much so, in fact, that statisticians and market research organizations are questioning the value of consumer buying expectation surveys altogether. One such influential body to drop consumer surveys of this nature is the eminent U.S. Bureau of the Census, and this after 13 years of sampling 12500 homes.

According to a report in Advertising $A g e^{5}$ the reason given by Acting Census Director Vincent $P$. Barabbas for dropping this survey was that predictions did not compare well with actual results. George $\mathrm{H}$. Brown, the well-known statistician, was quoted in the same report as saying the bureau has better ways to spend the $\$ 500,000$ required for this survey than to tinker with something which is neither accurate nor useful'. In addition, many other leading businessmen such as Thomas Juster of the National Bureau of Economic Research claimed that predictions by such a census served little purpose. He said that his organization's buying plan series 'has performed just as poorly' as the Census surveys. Jay Stark of General Motors expressed the opinion that the effort to measure expected purchases is a futile one, and Arthur Charous of Sears, Roebuck \& Co. found that the Census quarterly report entirely missed the turning point in late 1971 when household durables sales increased sharply. John Frechtling, representing Ford, agreed that a survey which does not assist predictions during periods of rapid change is not worth much.

This quite remarkable commentary on the inaccuracy of consumer buying expectation surveys leads one to wonder how many other marketing ideas, theories and procedures may be doubted. Marketing is not an 'exact science', this we know.

Nevertheless, as a discipline it has a set of rules, regulations and principles which try to explain what is happening in the market place. Some marketers believe that these same rules, regulations and principles can be used to describe and predict future consumer behaviour. Such a belief discounts the oft-repeated statement that we are living in a world of change. Only if there is an economic status quo can market forecasting be a valid, practical technique worthy of considerable analysis. If, as I believe, economic history does not repeat itself, then the forecast, especially the long-term forecast, serves little practical purpose.

Of course, all this is very debatable and it would be dogmatic to suggest that one cannot predict. But the fact that there are so many theories about 'how to' predict, is a reflection on man's inability to predict accurately. However, our concern is not with the accuracy of the prediction but with its validity. An accurate prediction for the wrong reasons is not valid. It is merely guess-work. Often we hear the phrase, "with hindsight we could have been more accurate in our predictions if we had assessed . . .' or, 'with hindsight it can be seen that . . ' - With hindsight! How very excellent we become at analysing what has taken place, safe in the knowledge that no matter how preposterous our theories (example: Jevons, H. L. Moore's sunspot-weather crop theories), nobody can dispute them. It is a pity that nobody has hindsight into the future!

\section{Implications for the Marketer}

There is a serious implication to all this: if we are prepared to doubt the validity of consumer buying expectation surveys, can we not just as well doubt the validity of other marketing or economic concepts? In other words, does economic theory have practical application? For only if we can establish the validity of economic theory in real-life situations, can we make inferences about future action by consumers with any degree of confidence.

The practical implications of concepts like 'marginal utility' and 'rationalization', for example, seem extremely limited. These concepts (as well as many others not discussed in this short paper) seem nebulous in definition and inadequate as a means of explaining consumer behaviour.

Economists hold that each individual has economic needs or wants. To satisfy these wants or needs the individual must choose between alternative courses of action and these courses of action will be governed by three things: 
- What is available in the marketplace

- How much money the individual has to spend

- His or her criterion of selection, i.e. preferences, buying wishes.

As each individual has preferences for products ranked in an order according to the degrees of enjoyment or satisfaction that each purchase provides, the only limitations placed upon individual consumer choice are what is actually available and what he can afford. Of course, in society there are also social limitations. As Howard Roseborough ${ }^{6}$ has pointed out: 'A man, for example, cannot live in sumptuous splendour and, with impunity, keep his wife and children in rags and at a starvation level.'

In deciding to make a purchase, the consumer is influenced by two factors: his disposable income (what he has to spend) and the commodity prices (what each article costs). Because fixed income and fixed market prices imply limited consumption possibilities, the consumer's purchasing intentions are at an equilibrium where the slope of his consumption possibility budget line is exactly equal to the slope of his indifference curve. ${ }^{7}$ Specifically, this means that a consumer with a fixed income will seek to maximize the satisfaction or utility of his or her purchase by comparing the marginal utilities per rand spent on one product with the marginal utilities per rand spent on some other goods. If any one product gives a greater marginal utility per rand, the consumer will gain by taking money away from other goods and spending more on that product - up to the point where the law of diminishing marginal utility sets in and brings the marginal utility of that product down to the equilibrium level.

This is fine in theory, as a description of what should happen. However, there is little evidence to suggest that consumers do act in this way, that they do shop around to get 'the best value for money', or even that they are aware of what their 'greatest satisfaction' is.

As the example on durable goods, has shown the consumer is continually changing his mind so that within a short period of time he may undergo radical changes in preference for products, even though market prices for commodities and the amount of money he has to spend (i.e. his disposable income) remain stable. We can say that 'the consumer ought to buy this commodity . . $\therefore$ 'ought to buy that commodity ....' and we can give sound economic reasons for our judgement; but we can never say that such action will happen. This is because the 'fundamental condition' of economic behaviour, namely that there is a relationship between marginal utility and price, is not acted upon in the same way by individual consumers.

Marginal utility, then, has the very real weakness that it does not lend itself to precise definition. All we can say is that: 'Marginal utilities are proportional to prices. That is always true, whether or not the general situation is one of equilibrium. But it is nothing more than a statement that consumers spend their incomes in the ways which they prefer.' ${ }^{8}$

The concept of 'rationalization' also leaves us with the feeling that it is a rather empty term. We can say that man should apply logic and intelligence to achieve the 'best buy'. But there is absolutely no objective way of determining which article a consumer should buy, given a relatively unlimited range of choice and a relatively unlimited range of needs. If consumer choice were influenced by income, price levels and the nature of the goods in a determinable way, statisticians would have no difficulty in predicting future consumer demand. In practice, buying decisions for products or services are based on the consumer's own scale of values of what is desirable, and thus highly subjective. 'We may look around us and say that a certain person is not doing the thing for which he is best suited, that the government is putting too much money into this or that project, that a certain store is not maximizing profits, and so on. But such observations merely reflect our judgement about what makes other people satisfied. There is no scientific way of proving that other people are making irrational choices.'

\section{Quo Vadis?}

It has been suggested in the foregoing that it is extremely difficult to predict consumer behaviour; firstly, because there are no fixed values in a world of change; secondly, because there is no logical way of determining the utility a product has for an individual; thirdly, because there is no way of rationalizing optimal choice; i.e. 'best choice' or 'optimal choice' for the consumer cannot be determined.

While these might seem almost insurmountable difficulties for the researcher to overcome, they do in fact suggest to marketers a new approach to the analysis of consumer behaviour - recognize change for what it is; acknowledge that utility cannot be accurately assessed but that opinion can be moulded; examine how consumer 'value judgements' come about and evaluate the significance of this for the marketing plan.

In attempting this new assessment, we become aware of a weakness in the argument presented so far, and that is: We have been looking at the consumer as an individual, while we market not to individuals but to groups within society. It is a mistake to think that, because we cannot predict how the individual will react, we shall not be able to analyse the society in which he is living or to predict the requirements of that society. Indeed, observation of the growth and complexity of a society, its wants, its needs, is one of the best ways of getting insight into future markets. Alfred Marshall in his book The Structure of Social Action observed that activities give rise to wants. That is why the study of society is so important. For as the number of activities in society increase (and the standard of living rises), so does the range of wants. People feel they want and 'need' items such as sport and camping equipment, swimming pools, television, air conditioning and central heating, all of which have little to do with the absolute 'musts' of food, clothing and shelter.

\section{The Need to Anticipate Change}

Recognizing change for what it is, has little to do with extrapolating past trends into the future. Rather, it is concerned with the real cause of change and how the change will affect society and markets. John Landell-Mills ${ }^{10}$ talks of 'probing and monitoring future developments in social trends and attitudes that could affect and influence the company'. He mentions the pollution problem, the rising demand for some kind of individual democracy and meaningful worker participation, the rejection of monotonous, soul-destroying assembly line life. These are the clues to future markets, and it is the marketer's task to turn information of this nature into actionable elements.

This can be done - by thinking of the significance of change: Pollution control - new markets for smokeless coal 
stoves; the petroleum and oil crises - growth market for bicycles; the need for energy conservation and use of natural resources - solar heaters; traffic congestion and the general decay of downtown areas - increase in food take-aways and re-emergence of the home as a focal point of entertainment; increase in the crime rate - boom in the sales of burglar alarm systems, and so on.

Today's consumer is a product of our Age of Affluence and of his own rising level of expectations. Only by studying the whole hierarchy of structures and sub-structures which together comprise the consumers' social system shall we be able to establish what these expectations are, and market successfully to these people.

This is not an easy task. Howard Roseborough ${ }^{6}$ has suggested that an analysis of life styles, standards of living, consumption standards, social group participation and individual standards is prerequisite to making specific evaluations as to what the consumer will buy. It should be realized, though, that these same life styles, standards of living, consumption standards, etc. are a result of mass communication, the result of an effective transmission of ideas in society. Ideas decide destinies; and advertising is the classic example of communication art. Through advertising, not only are the availability of products and services announced and awareness levels for product and services created, but more than this, society is moulded in that it is given a range of desires, expectations and values from which consumer choice becomes effective.

\section{The Art of Persuasion}

Here then is the element economic theory leaves out: the art of persuasion. Mass communication forms society. Individuals in society do not relate the marginal utility of a commodity to price except in so far as advertisers tell them they should. Consumer buying decisions regarding products or services are not based on independent objective standards, but on advertisers' standards. The significance of this is that advertisers can and do mould society by telling them what to do, what to believe and how to behave.

There are, of course, a number of different standards that are fostered by advertisements, such as social standards the need for hygiene (deodorants, soaps, toothpastes, polishes); the need for prestige (cars, clothes); the need for security (home ownership, insurance), and so on; and economic standards - related to factors such as price, finish, quality, warranties, after sales service, etc. Because these standards are on the whole readily accepted by consumers, advertisers have a very real responsibility to maintain them, both socially and economically.

Unhappily, however, economic responsibility has been abused both by advertisers (who make exaggerated claims for products and services) and by suppliers (whose products deteriorate in quality below consumer expectations). This has resulted in a consumer credibility gap. An extract from a 'Good Housekeeping' advertisement sums it up as follows: 'If she doesn't believe you, she loves you not. That's the way it is with today's sceptical consumer. And agencies and advertisers alike know it. They recognize that the way to persuade her is with advertising that is as informative as it is interesting. With words and ideas that touch her mind as well as her heart. . . . The more believable the medium, the more believable the message. . . . Which is something to remember when you realize that one of the most challenging problems your ad now faces is simply to be believed.' 11

\section{Consumerism}

The difference between what is claimed for products and services by advertisers and what is found in actual products and services led to consumer disillusionment, hostility and the awakening of a new social movement - consumerism: the name given to that movement started under Ralph Nader's aegis, in which the consumer demands better quality products, product warranties that are meaningful and enforceable, and value for money spent.

A result of this movement is that consumers have become more aware and critical of products (and services) offered in the market place and demand higher standards of packaging, product excellence, service facilities, etc. In addition the movement has resulted in a growing awareness that social responsibility does not end with the buying function, e.g. criticisms of certain cars 'unsafe at any speed', the printing of health warnings on cigarette packets, outcries against chemical plant effluent and so on. Marketers who are aware of the significance of consumerism have been able to anticipate changes in economic and social attitudes and plan their marketing strategy accordingly. Such anticipation is the competitive edge'.

No paper of this nature can hope to come up with profound, earth-shattering solutions as to why the individual behaves as he does, or why society acts in the way it does. At best one can only make suggestions, hoping that some of these ideas challenge the old establishment wisely and that other ideas provide food for further thought. But what seems fundamentally important is to establish as clearly as possible the future direction of consumer behaviour.

\section{The Future of Consumer Research?}

Perhaps Michael Lane ${ }^{12}$ provides a clue when he writes: 'In mass communication, in terms of the actor-role situation, the individual tends to disappear.' Perhaps he is right; the consumer - swamped and bombarded daily by messages, directions, signs - has lost his identity, his 'raison d'être' and must inevitably seek to regain it. 'Man craves most of all a sense of purpose, a role in life and in society. Deny him that, make him feel of no consequence, and he will take revenge by overturning any economic system, however well regulated. It is not enough to offer him value for his money in goods and services. He must have a place to match his sense of merit - something to admire and defend, entertainment and amusement, responsibility and initiative. Without these, goods and services are as dust and ashes, and any one input is as far from ideal as any other.' ${ }^{13}$

This, then, could be the direction of future consumer research: to analyse and assess the 'human condition' in order to find out how man develops goals in life, and to establish the way in which consumer products relate to these goals, for, "immediately we begin to think of wants as fused by a sense of purpose, the tool of marginal analysis breaks in our hands. It is borne in on us that it is not just the surface wants that cry out for satisfaction, but the deeper urges which they often express. People buy goods not for their own sake so much as for what they symbolize. ${ }^{13}$ Perhaps it will be through a study of these 'symbols' that we shall find the key to consumer choice. Yet, establishing how these symbols come into being will not be easy, for, as Dostoyevsky so eloquently puts it: "The fact is, gentlemen, it seems there must really exist something that is dearer to almost every man than his greatest advantages .. . This advantage is remarkable from the very fact that it breaks 
down all our classifications and continually shatters every system constructed by lovers of mankind for the benefit of mankind ... What man wants is simply independent choice, whatever that independence may cost and wherever it may lead. And choice, of course, the devil only knows what choice. ${ }^{14}$

\section{References}

1 MORONEY, M. J. 1951. Facts from Figures. Pelican Original, p. 324.

2 Starch, Daniel \& Staff, March, 1955. What makes People Read Advertisements? Tested Copy.

3 HOPNER, H. W. 1956. A National Survey of Major Purchases. Published by National Family Options, Inc., Toledo, Ohio, USA. Modern Adveriising, Practices and Principles, McGraw-Hill.

4 FRB Survey of Consumer Finances, Federal Reserve Bulletins, July 1951 and August 1952.

5 Advertising Age, 25 June 1973, p. 4.

6 ROSEBOROUGH HOWARD, 1965. Some Sociological Dimensions of Consumer Spending. Readings on Economic Sociology, Neil J. Smelser (ed.), Prentice-Hall Inc., New Jersey.

7 SAMUELSON, PAUL A. 1970. Economics. McGraw-Hill, New York, Ch. 22.

8 BENHAM, FREDERIC, 1961. Economics. Pitman, London, p. 252.

9 MUNDELL, ROBERT A, 1968. Man and Economics. McGraw-Hill, New York.

10 LANDELL-MILLS, JOHN, 1973. Corporate Image Research. Marketing in Southern Africa 2(3), June-July.

11 Advertising Age, 6 August 1973.

12 LANE, MICHAEL, 1973. Communication, a Two-way Process. Marketing in Southern Africa 2(3), April-May.

13 CAIRNCROSS, ALEC, 1966. Introduction to Economics. Butterworths, London, p. 285.

14 DOSTOYEVSKY, FYODOR, 1962. Notes from Underground. Quoted in: Robert G. Olson's An Introduction to Existentialism. Dover Publications, New York, p. 21. 